2016

\title{
Ceramic Sherds from the Millsey Williamson Site (41RK3), Rusk County, Texas
}

Timothy K. Perttula

Heritage Research Center, Stephen F. Austin State University

Follow this and additional works at: https://scholarworks.sfasu.edu/ita

Part of the American Material Culture Commons, Archaeological Anthropology Commons, Environmental Studies Commons, Other American Studies Commons, Other Arts and Humanities Commons, Other History of Art, Architecture, and Archaeology Commons, and the United States History Commons

Tell us how this article helped you.

This Article is brought to you for free and open access by the Center for Regional Heritage Research at SFA ScholarWorks. It has been accepted for inclusion in Index of Texas Archaeology: Open Access Gray Literature from the Lone Star State by an authorized editor of SFA ScholarWorks. For more information, please contact cdsscholarworks@sfasu.edu. 
Ceramic Sherds from the Millsey Williamson Site (41RK3), Rusk County, Texas

Creative Commons License

(c) $($ ) $(9)$

This work is licensed under a Creative Commons Attribution-NonCommercial 4.0 International License 


\title{
Ceramic Sherds from the Millsey Williamson Site (41RK3), Rusk County, Texas
}

\author{
Timothy K. Perttula
}

\section{INTRODUCTION AND CULTURAL CONTEXT}

The Millsey Williamson site (41RK3) is an $18^{\text {th }}$ century Nadaco Caddo settlement and cemetery situated on an alluvial terrace on the east side of Martin Creek (Jones 1968) in the Sabine River basin (Figure 1). Some portions of the site are now covered by the waters of Martin Creek Lake, constructed in the 1970s. The site was first investigated in the 1930s, when at least 11 historic Caddo burials were excavated in the cemetery at the western end of the landform (see Jones 1968:Figure 5). Buddy Calvin Jones excavated a disturbed historic burial at the site in 1955, and also occasionally collected glass beads from the surface of the site. The funerary offerings placed with this disturbed burial were not clearly enumerated by Jones, as his description of artifacts from the site included artifacts he examined in several other collections.

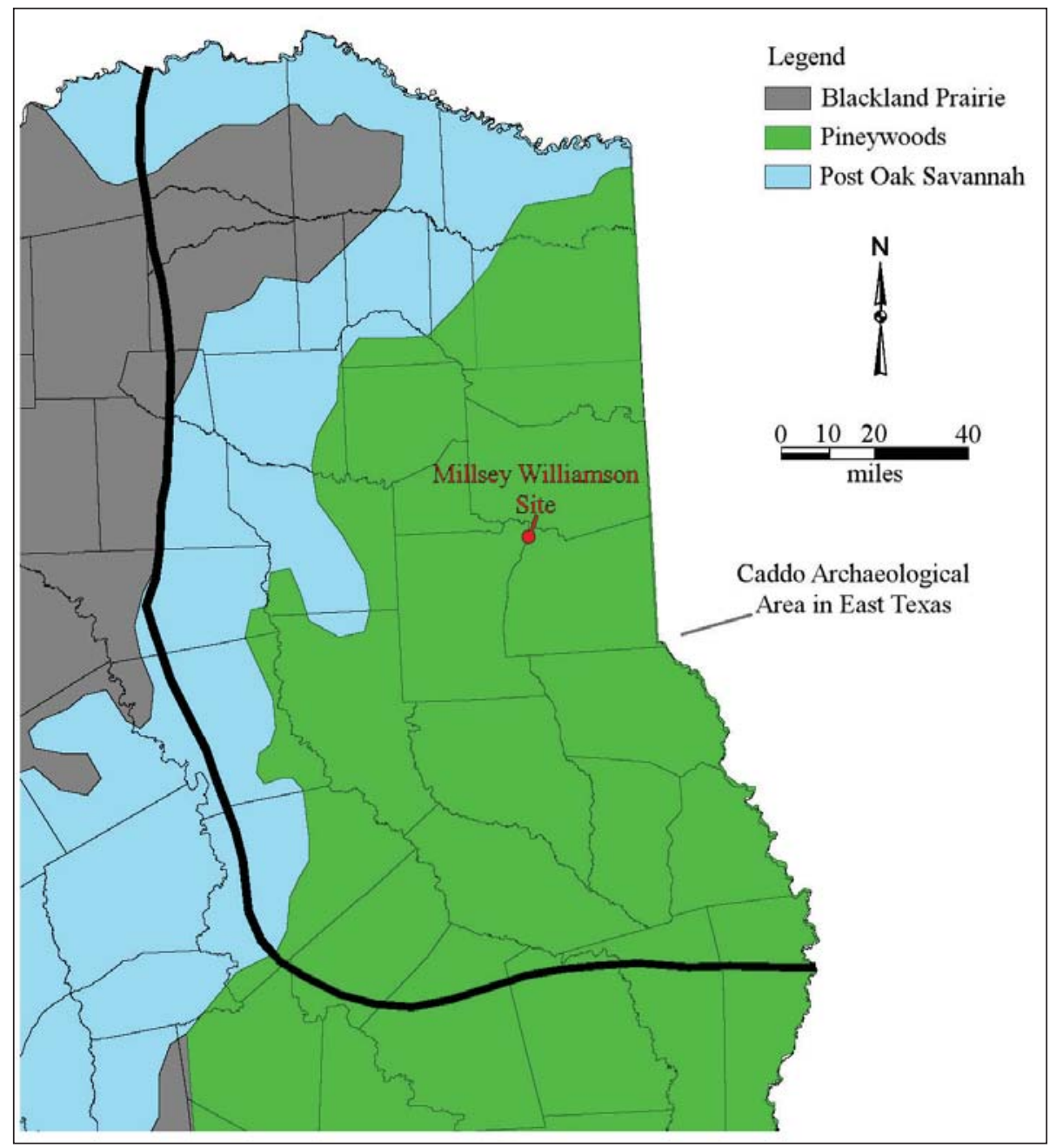

Figure 1. Location of the Millsey Williamson site (41RK3) in East Texas. 
He did note 275 sherds from the surface of the site and 12 whole or restored ceramic vessels from an unknown number of burials (Jones 1968:Table 1). Most of these sherds were recorded by Jones as being grog- (52 percent) or bone-tempered (43 percent), but 4 percent were tempered with shell. Perttula and Nelson (2014) recently documented 11 vessels from the Millsey Williamson site in the collections of the Gregg County Historical Museum (GCHM). These vessels include a Emory Punctated-Incised (shelltempered) collared jar; a Maydelle Incised jar; a Bullard Brushed jar; a jar with brushing only on the body; a Ripley Engraved, var. unspecified carinated bowl; Simms Incised carinated bowl; two unidentified engraved carinated bowls with a continuous stepped rectilinear scroll design; a carinated bowl with a sprocket rim with a continuous negative scroll design; a carinated bowl with diagonal opposed and cross-hatched engraved lines on the rim; and a plain olla. The ceramic vessels are of diverse manufacture, form, and decorative methods. Most are carinated bowls and jars tempered with grog and bone, and fired in a reducing environment, and the former are decorated with engraved lines, while the latter are decorated incised, punctated, or brushed utility wares. On their own stylistic merits, none of these vessels in the GCHM collections is that of a recognizable Historic Caddo type, such as Natchitoches Engraved, Simms Engraved, var. Darco, or Keno Trailed, and in fact, most of these vessels cannot be identified as examples of specific types. The vessels that can be typed include Emory Punctated-Incised, Maydelle Incised, and Bullard Brushed jars and a Ripley Engraved, var. unspecified carinated bowl; one vessel has been dubbed Simms Incised because it is of a form and decorative style that matches Simms Engraved, except the motif is executed with incised lines.

Also recovered from the site were clay and limonite pipes, ochre and vermillion, animal teeth, glass beads, metal gun parts, gun flints, iron knives, iron arrow points, and awls in the Millsey Williamson collection. There were also a variety of brass objects: a brass tinkler, coils, hawk bells, and unworked pieces of sheet brass.

\section{Ceramic Sherd Assemblage}

The available ceramic sherd assemblage from the Millsey Williamson site in the GCHM collection includes 81 plain and decorated sherds from plain, utility, and fine ware vessels (Table 1). These sherds may be part of the previously mentioned surface collection obtained from the site by Jones (1968).

Table 1. Ceramic sherd assemblage from the Millsey Williamson site.

\begin{tabular}{llccc}
\hline Ware & Shell- & Grog-tempered & Bone-tempered & N \\
& Tempered & & & \\
\hline Plain & 1 & 21 & 31 & 53 \\
Utility & - & 7 & 20 & 27 \\
Fine & - & - & 1 & 1 \\
\hline Totals & 1 & 28 & 52 & 81 \\
\hline
\end{tabular}

The majority of the ceramic sherds are from bone-tempered vessels (64.2 percent), but other sherds are from grog-tempered vessels (34.6 percent) (see Table 1) One plain body sherd (1.2 percent) is from a shell-tempered vessel, and this vessel was likely made by a Caddo potter living in a community along the Red River to the east or north (Perttula et al. 2012; Selden et al. 2014) of the Millsey Williamson site where shell-tempered vessels were commonly manufactured and used.

The sherds from utility ware vessels in this collection primarily have brushed decorative elements (66.7 percent) or are from vessels with secondary incised or punctated elements (Table 2). The sherds with brushed-incised and brushed-punctated decorative elements comprise another 11.1 percent of the utility ware sherd assemblage. These different decorated sherds are likely from Bullard Brushed jars. 
Table 2. Decorative methods and elements in the utility ware sherds from the Millsey Williamson site.

Decorative method/

$\operatorname{Rim}$

Body

$\mathrm{N}$

Decorative element

Brushed

parallel brushing marks

$-\quad 18$

18

\section{Brushed-Incised}

parallel brushed with overlying parallel incised lines

\section{Brushed-Punctated}

diagonal brushing marks and adjacent tool punctated row

tool punctated row and vertical brushing marks

\section{Incised}

cross-hatched lines

opposed lines

broad parallel lines

broad straight line

\section{Incised-Punctated}

horizontal and curvilinear zone filled with

circular punctations

$-$$$
-
$$

-
-
-
-

$\begin{array}{lll}- & 1 & 1 \\ - & 1 & 1\end{array}$

Punctated

tool punctated rows

$-$

Totals

$-$

27

27

Other utility ware sherds include a few from incised (14.8 percent), incised-punctated ( 3.7 percent), and punctated (3.7 percent) vessels (see Table 2). The incised and incised-punctated (Figure 2) sherds are from Maydelle Incised vessels.

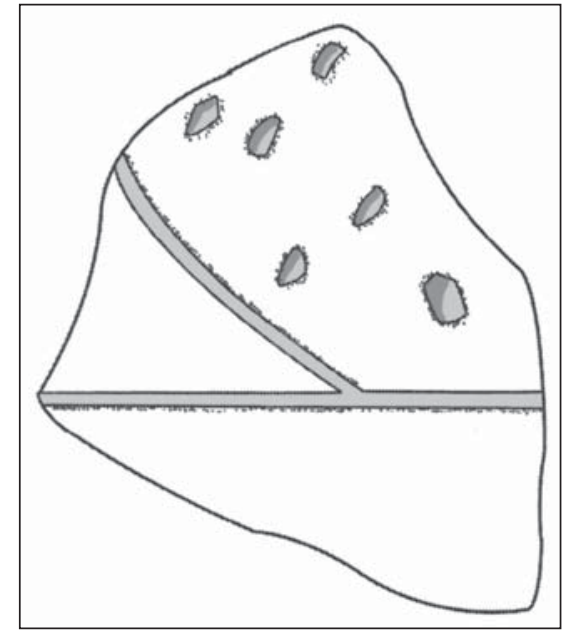

Figure 2. Incised-punctated body sherd from the Millsey Williamson site. 
The one fine ware sherd in this assemblage represents only 3.3 percent of the decorated sherd assemblage in this collection from the Millsey Williamson site. It is a bone-tempered rim sherd with a single horizontal engraved line under the lip.

\section{SUMMARY}

The high frequency of brushed sherds in the decorated sherd assemblage at the Millsey Williamson site, as well as the common use of bone temper in vessel manufacture (e.g., Dockall and Fields 2011), suggest that the ceramic sherd assemblage at the Millsey Williamson site dates well after ca. A.D. 1450. Dockall and Fields (2011) have noted that the use of bone temper increased through time in middle Sabine River archaeological sites, as sherds with bone temper in earlier Middle Caddo period (ca. A.D. 12001400) components at 41HS231, 41HS574, 41HS844, and 41HS846 account for only 10-37 percent of the vessel sherd assemblages, but this proportion increases to more than 50 percent at post- $15^{\text {th }}$ century sites/ components at Pine Tree Mound (41HS15) (Fields and Gadus 2012), 41HS573, 41HS843, and 41RK557. These post-A.D. 1450 ceramic assemblages are dominated by brushed wares, comprising more than 50 percent of the decorated sherd assemblages.

There are no sherds in the assemblage at the Millsey Williamson site that can be identified as belonging to a post-A.D. 1680 Caddo ceramic assemblage. It is likely the case, then, that the small ceramic assemblage from the Millsey Williamson site discussed in this article represents an occupation by $16^{\text {th }}$ to $17^{\text {th }}$ century Caddo peoples probably affiliated with a Nadaco Caddo community.

\section{ACKNOWLEDGMENTS}

I thank Patti Haskins of the Gregg County Historical Museum for all her help in completing the documentation of these materials from the Millsey Williamson site. Lance Trask prepared the figures in this article.

\section{REFERENCES CITED}

Dockall, J. E. and R. C. Fields

2011 National Register Testing of Three Sites in the Sabine Mine's South Hallsville No. 1 Mine-Rusk Permit, Rusk County, Texas. Report of Investigations No. 162. Prewitt and Associates, Inc., Austin

Fields, R. C. and E. F. Gadus (editors)

2012 Archeology of the Nadaco Caddo: The View from the Pine Tree Mound Site (41HS15), Harrison County, Texas. 2 Vols. Reports of Investigations No. 164. Prewitt and Associates, Inc., Austin.

Jones, B. C.

1968 The Kinsloe Focus: A Study of Seven Historic Caddoan Sites in Northeast Texas. Master's thesis, Department of Anthropology, University of Oklahoma, Norman.

Perttula, T. K. and B. Nelson

2014 The Millsey Williamson (41RK3), Bead Burial, and L. N. Morwell Farm Sites on Martin Creek: Historic Caddo Settlements along Trammels Trace, Rusk County, Texas. Journal of Northeast Texas Archaeology $44: 23-46$.

Perttula, T. K., M. B. Trubitt, and J. S. Girard

2012 The Use of Shell-Tempered Pottery in the Caddo Area of the Southeastern United States. Southeastern Archaeology 30(2):242-267.

Selden, R. Z., Jr., T. K. Perttula, and D. L. Carlson

2014 INAA and the Provenance of Shell-Tempered Sherds in the Ancestral Caddo Region. Journal of Archaeological Science 47:113-120. 